\title{
Normative aspects of climate adaptation policies
}

\author{
Peter P.J. Driessen and Helena F.M.W. van Rijswick*
}

\begin{abstract}
Adaptation to climate change is a complex process of societal change and should be studied as such. Attention to issues of climate adaptation has increased considerably over the past few years. Until now, less attention has been paid to questions concerning normative issues of societal change. In this paper we will address three important questions on the normative level: (a) What kind of legal and policy principles should public and private actors take to heart when formulating and implementing adaptation measures? (b) Which societal interests should be protected by a climate-adaptation policy and in what order? (c) To what extent are governments responsible for adaptation to climate change and what are the responsibilities to be borne by private parties and citizens? We will treat these questions from a mix of legal, administrative, and economic perspectives. We conclude with some recommendations on how to deal with these normative aspects in policy-making processes.
\end{abstract}

\section{INTRODUCTION}

The amount of attention given to climate adaptation has increased dramatically over the past few years. The reason for this is that the effect of mitigation efforts intended to restrict the increase in the Earth's average temperature by reducing greenhouse gas emissions will probably be inadequate, and these mitigation efforts will certainly not lead to results in the short and medium term. Moreover, there has been an increase in awareness that the consequences of

* This paper is the result of a multidisciplinary research project that was sponsored by the Dutch national research programme Knowledge for Climate (www.climateresearchnetherlands.nl). The same research programme is financing a follow-up multidisciplinary research project called 'Governance of Adaptation' (http://knowledgeforclimate.climateresearchnetherlands.nl/governanceofadaptation). Peter P. J. Driessen is Professor of Environmental Studies, Copernicus Institute of Sustainable Development, Faculty of Geosciences, Utrecht University, the Netherlands (E-mail: p.driessen@uu.nl). Helena F. M. W. van Rijswick is Professor of European and Dutch Water Law, Faculty of Law, Economics and Governance, Utrecht University, the Netherlands (E-mail: H.vanRijswick@uu.nl). The authors wish to thank the Editor of Climate Law for extensive feedback during the review process. 
climate change can be extremely serious and can lead to social disruption. ${ }^{1}$ The societal impacts of climate change are varied: threats to water safety, loss of biodiversity, economic damage, and other effects in a variety of social sectors, such as human habitation (heat stress in urban areas, urban flooding), agriculture (salinization, aridity, rural flooding), infrastructure (disruption), and food supplies (threats to agricultural production). The threats to public health have also been given more attention over the past few years. ${ }^{2}$ Climate change is not only a threat, however; opportunities may arise for new economic development, such as in the agricultural sector with the cultivation of alternative crops.

Adaptation to climate change is complex for several reasons. ${ }^{3}$ First, it is a matter of uncertainty and ambiguity. The knowledge base for defining the problem and identifying possible solutions is both insufficient and disputed: what, exactly, is the problem and what specific actions should be undertaken? Second, confusion results from multiple interpretations and framing differences. The nature of the problem and the human role therein are continuously being debated from a normative and scientific angle. Furthermore, investment in adaptation is not only a matter of infrastructural adjustment, like building dikes and improving irrigation, waste, or drinking systems; it also involves broader issues such as ecology, agriculture, urban and regional planning, nature preservation, and energy supply.

Climate change is a global phenomenon and it therefore requires collective and international agency. This implies scaling problems, as the effects are felt at the national, regional, and local levels. In practice, they are either the result of implementing adaptation measures or the consequence of not doing so. Threats and opportunities deriving from climate change differ from place to place; moreover, climate adaptation takes place in a multi-actor setting. Together, these processes blur the traditional boundaries between countries, between administrative scales, between the public and the private sector, and, last but not least, between the international, supranational, national, regional, private, administrative, and environmental legal regimes. At each of these levels, the actors contribute a variety of values, interests, resources, and perspectives. The problem cuts across the jurisdictions and routines of organizations and sectors. Moreover, the dynamism of the social and ecological processes requires long-term horizons, which in turn demand a specific commitment by taxpayers, politicians, and scientists. Despite the panoramic perspectives of the predictions, adaptation is also a matter of the here and now. People expect that they will be safeguarded by the government from flooding, drought, and the health effects of climate change. As a consequence, climate adaptation requires a constant interplay between short-term intervention and long-term vision.

\footnotetext{
${ }^{1}$ IPCC, Climate Change. The Fourth Assessment Report, WMO (2007); European Commission White paper COM (2009) 147. Adapting to climate change; towards a European framework for action; EEA, Impacts of Europe's changing climate 2008 indicator-based assessment. Report no 4/2008, Copenhagen, 2008.

${ }^{2}$ Anthony Costello et al., Managing the health effects of climate change, 373 The Lancet 2009, pp. 1693-1733.

${ }^{3}$ Peter P. J. Driessen, Kim van Nieuwaal, Tejo Spit, and Katrien Termeer, Bestuurskundig onderzoek naar klimaatvraagstukken, in Klimaatneutrale of klimaatbestendige bestuurskunde? 18 (4) Bestuurskunde 7 (2009); Heleen Mees and Peter P. J. Driessen, Adaptation to climate change in urban areas: climate-greening London, Rotterdam, and Toronto, 2(2) Climate Law 251 (2011).
} 
It is thus fair to say that adaptation to climate change is not only, or not particularly, a technical issue. Rather, it is a complex process of societal change and should be studied as such. ${ }^{4}$ It requires difficult, non-evident, and often contradictory solutions in the face of uncertainty, as well as large-scale environmental and social change, involving many actors in society from different institutions and with different value systems. ${ }^{5}$

While many definitions of adaptation to climate change are in circulation, one of the most commonly used definitions is the IPCC's, which defines adaptation as "the adjustment in natural or human systems in response to actual or expected climatic stimuli or their effects, which moderates harm or exploits beneficial opportunities". 6 Thus adaptation measures deal with avoiding or reducing climate change impacts for current and future generations. Adger and colleagues describe the three cornerstones of adaptation as: "reduce the sensitivity of the system to climate change; alter the exposure of the system to climate change; and increase the resilience of the system to cope with changes". 7 Sensitivity and exposure are often linked to "vulnerability". 8 Resilience, a concept originating within the domain of natural science to address changes in equilibria in ecological systems, has entered the field of social sciences related to the study of socio-ecological systems. ${ }^{9}$ Resilience is often used to mean the amount of change or disturbance that a socio-ecological system can absorb and persist with before it is reorganized into a new equilibrium. ${ }^{10}$ Although there is much debate about the two concepts and their interrelations, we view vulnerability and resilience as being opposites. In this view, high levels of vulnerability mean low levels of resilience and the converse. A policy directed towards climate adaptation may thus be described as aiming to decrease the vulnerability of a system to climate change and increase the system's resilience in coping with climate change.

In a legal context, vulnerability and resilience may have specific meanings. Vulnerability may refer to a duty of care, for instance the protection of the living environment and public health. Resilience may relate to the strength and flexibility of a legal system to cope with problems of climate change. The law is meant to offer a stable basis for organization, as well as legal certainty and protection against unlawful or arbitrary behaviour. Legal resilience is therefore

\footnotetext{
${ }^{4}$ See Catrien Termeer, Art Dewulf, Helena van Rijswick, Arwin van Buuren, Dave Huitema, Sander Meijerink, Tim Rayner and Mark Wiering, The regional governance of climate adaptation: A framework for developing legitimate, effective and resilient governance arrangements, in which a multidisciplinary approach is being developed for the governance aspects of adaptation to climate change.

${ }^{5}$ Irene Lorenzi, Mavis Jones, and John R. Turnpenny, Climate change, human genetics and post-normality in the $U K, 39$ Futures 65 (2007).

${ }^{6}$ IPCC, Climate Change: The Fourth Assessment Report, 2007.

${ }^{7}$ W. Neil Adger, Nigel W. Arnell, and Emma L. Tompkins, Successful adaptation to climate change across scales, 15 Global Environmental Change 77 (2005).

${ }^{8}$ W. Neil Adger, Vulnerability, 16 Global Environmental Change 268 (2006).

${ }^{9}$ Carl Folke, Resilience: The emergence of a perspective for socio-ecological systems analyses, 16 Global Environmental Change 253 (2006).

${ }^{10}$ C. S. Holling, Resilience and stability of ecological systems, 4 Annual Review of Ecology and Systematics 1 (1973).
} 
limited among other things by the rule of law and the need for legal certainty. ${ }^{11}$ Our argument is that a legal system should support, or at least not counteract, adaptation policies and still safeguard legal certainty and the rule of law. Therefore, clarity is needed as to the main normative goals in society and the way in which responsibilities are shared between public and private parties.

In this paper we discuss normative aspects of climate adaptation, as they influence or should influence international, national, and regional climate-adaptation policies. Starting from a general and international perspective, we use examples from European and Dutch climate-adaptation law and policy to illustrate our argument. The main reason for this choice is that we have familiarity with legislation and policies in Europe and in particular the Netherlands. Nevertheless, we expect that our analysis is relevant for, and applicable to, other regions in the world that have to deal with the same threats.

\section{Normative Legitimation of Adaptation to Climate Change}

While there is an increasing attention to the issue of climate adaptation, less attention has been given so far to the normative aspects of the problem. A policy directed towards climate adaptation is always value-laden. Normative judgements can be based on world views and principles as to what should, and what should not, be done in our society, and on the societal and economic interests that are at stake. ${ }^{12}$ Some of these normative opinions are embedded in national legislation and regulations (and, in Europe, at the EU level), for instance in the form of guiding principles and standards. Other normative positions are not similarly embedded, and as a result can vary considerably in time and place. Normative aspects are occasionally touched upon in the academic debate on climate adaptation, but seldom are they brought into the open. ${ }^{13}$ We feel that insufficient light has been shed on three questions at the normative level:

- Which legal and policy principles should public and private actors take to heart when formulating and implementing adaptation measures?

${ }^{11}$ Jonas Ebbesson, The rule of law in the governance of complex socio-ecological changes, Global Environmental Change 20 (2010); Jutta Brunné, and Stephen T. Toope, Legitimacy and legality in international law, an interactional account (2010); Helena van Rijswick, Moving water and the law, on the distribution of water rights and water duties within river basins in European and Dutch water law (2008).

${ }^{12}$ Helena van Rijswick and Willem Salet, Een strategisch kompas voor duurzame beheersing van klimaatvraagstukken, 37(1) Beleid en Maatschappij 43 (2010).

${ }^{13}$ Rosalind Cook, Legal responses for adaptation to climate change. The role of the principle of Equity and Common but differentiated responsibility (2010), available at <www.milieurecht.nl $>$; Rosalind Cook and Eljalill Tauschinsky, Accommodating human values in the climate regime, 4(3) Utrecht Law Review 18 (2008); Antonius A. J. de Gier, Joyeeta Gupta, and Helena van Rijswick, State of the Art on the Legal and Policy Literature on Adaptation to Climate Change: Towards a Research Agenda, Kennis voor Klimaat, report nr. KfC001/09 (2009),

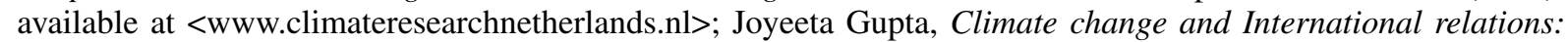
Urgent challenges anno 2000, in Jan H. G. van den Broek et al., Klimaatverandering en de rol van het recht (Climate change and the role of environmental law), 27. 
In most modern societies there are certain principles_often, but not always, embedded in laws and international treaties_-which are taken as points of departure for intervening or not intervening in societal processes. ${ }^{14}$ These points of departure must result in interventions being legitimate, both in the sense of "legally based" and "acceptable and transparent". A climate-adaptation policy can also be based on normative principles. The question then is, which principles and what legal meaning to assign to them?

- Which societal interests should be protected by a climate-adaptation policy and in what order?

This question focuses on the actual goals of a climate-adaptation policy. Policy goals are usually based not only on available scientific knowledge but on political and societal preferences. Moreover, there are often several paths that can lead a solution to a problem, and therefore there is choice. One crucial question in this respect is whether adaptation measures, or the legal and institutional system on which they are based, must be aimed wholly and specifically towards maintaining the current situation and protecting existing interests, or whether changes in the current situation are necessary, desired, permitted, or should be encouraged to improve the resilience and adaptive capacity of the system, and, if so, under what conditions.

- To what extent are governments responsible for adaptation to climate change and what are the responsibilities to be borne by private parties and citizens?

Concerning such an extensive social issue as climate change it is only natural to think of the government as the provider of solutions. Yet the problem-solving capacity of government is-as is evident from many legal, policy, and economic studies-limited. ${ }^{15}$ Because of this, it is worthwhile to consider other societal actors able to help with solutions. Furthermore, in principle it may be better to place some responsibility on societal organizations rather than on government. How should that division of responsibilities be visualized?

The above three questions are clearly interrelated. For instance, the nature of the legal and policy principles will influence the question of whether existing situations should or should not be maintained, and whether private parties do or do not have responsibility for climate adaptation.

The objective of this paper is to clarify the normative aspects of climate adaptation and indicate where societal choices are both necessary and beneficial. The aforementioned questions will be dealt with in succession, although we do not claim to answer them fully. After all, answers will differ according to different states or regions, depending on the main problems that have to be solved, the political preferences, historical views, the actual preferences as to how to deal

\footnotetext{
${ }^{14}$ Nicolas De Sadeleer, Environmental Principles: From Political Slogans to Legal Rules (2005); Maria Lee, EU Environmental Law: Challenges, Change and Decision-making (2005); Jan H. Jans and Hans D. Vedder, European Environmental Law (2008) 35-46; Richard Marcrory (ed.), Principles of European Environmental Law (2004).

${ }^{15}$ Helena van Rijswick and Willem Salet, supra note 12; Peter P. J. Driessen and Pieter Glasbergen (eds.), Greening society: The paradigm shift in Dutch environmental politics (2002).
} 
with certain public interests, ${ }^{16}$ the way a state is organized,,${ }^{17}$ and the obligations following from international and other law. More specifically, our goal is to present the main aspects that have to be considered when answering these questions and, by doing so, to put these questions and considerations on the adaptation agenda. Raising the questions invites policymakers and lawyers to reflect on the normative aspects of adaptation. Answering the questions is necessary for the transparency, and therefore legitimacy, of the solutions as well as the acceptance of the choices that have to be made.

\section{Which Legal and Policy Principles Should Take the Lead or Need Rethinking for Climate Adaptation?}

Climate change is a phenomenon that is not only complex but also entails major uncertainties. Modelling of climate change only allows estimates to be made. A situation of this kind is particularly troublesome. In acting too eagerly, investments will probably be made which in hindsight might not have been necessary. Waiting too long before implementing measures could mean that important adaptation options are no longer available, the cost of measures increases significantly, and the risk of disaster and societal disruption is intensified. In such a case we need to look to potential normative principles that we can use as guidelines for policy and decisionmaking, because consensus on normative principles may promote a more predictable and stable rule of climate law and policy. Principles are able to facilitate flexibility and resilience in further implementing adaptation policies and measures, because they provide a more general direction towards solutions for climate change and may avoid legal instrumentalism.

Some principles regarding climate change follow directly from the international legal framework, namely the UNFCCC. The UNFCCC is based on the idea that adaptation must be addressed with the same priority as mitigation. More general principles of international law might also be relevant, but principles derived directly from the UNFCCC will prevail, since they can be seen as lex specialis. Besides the principles deducible from the UNFCCC and its implementation in domestic law, most states rely on legal and policy principles that are of a more general kind within their legal system, but which are also relevant for national (and, in the European Union, regional) climate-adaptation policy. However, the role that normative principles play in practice will strongly depend on one's view on the public and private interests at stake. ${ }^{18}$

\footnotetext{
${ }^{16}$ Jurrien Hamer, Resilience in concepts of the Public Interest. A comparison of political-theoretical approaches, and their consequences for climate adaptation water policies, Utrecht University (2011); the author discusses libertarianism, free-market environmentalism, liberalism, Rawls's theory of justice, and communitarianism with regard to adaptation to climate change.

${ }^{17}$ Stefano Moroni, An Evolutionary Theory of Institutions and a Dynamic Approach to Reform, 9(4) Planning Theory 275 (2010); Elinor Ostrom, Understanding Institutional Diversity (2005); Willem Salet, Evolving institutions; an international exploration into planning and law, 22 Journal of Planning Education and Research 26 (2002).

${ }^{18}$ See Jurrien Hamer, supra note 16.
} 


\section{UNFCCC Principles}

We distinguish five main principles in the UNFCCC: equity, ${ }^{19}$ solidarity, ${ }^{20}$ precaution, ${ }^{21}$ sustainability, ${ }^{22}$ and good neighbourliness. ${ }^{23}$ The UNFCCC also recalls in its preamble that states, in accordance with the UN Charter and the principles of international law, have the sovereign right to exploit their own resources under their own environmental and developmental policies, and the responsibility to ensure that activities within their jurisdiction or control do not cause damage to the environment of other states or to areas beyond the limits of national jurisdiction.

The backbone of the UNFCCC is the principle of equity, laid down in Article $3 .{ }^{24}$ Equity concerns present generations as well as future generations. It concerns fairness, or, to be precise, substantive and procedural fairness. Distributive fairness is based on the principle of solidarity, and may require a rebalancing of inequalities in wealth, risk, and financial or other excessive burdens.

At the national level, in the administrative or environmental laws of many states, the principle of solidarity and the principle of distributional fairness may be recognized in what is called the compensation principle (egalité devant les charges publiques). If certain persons (instead of states as is the case in international law) suffer a loss that exceeds the loss that everyone else in society has to bear, then that loss must be compensated. This principle arises from the principles of equity and solidarity and is further developed in the principle of protection of property, respect for basic rights, and fair treatment. For example, major infrastructural works that provide essential energy or water supply often have particular consequences for certain individuals and call for disproportionate losses to be compensated. An important element of the compensation regime is the predictability of damage. The question arises whether and when measures that will be taken to adapt to climate change will affect the right to interpersonal compensation, and whether a more substantial change to compensation rights will be made, due to the fact that increased predictability will mean that there is no longer a right to compensation at all. Furthermore, the compensation principle may need rethinking when it comes to adaptation measures because it is often based on the status quo and may entrench a conservative attitude, whereas adaptation policies are not primarily concerned about preserving the status quo but are about adapting to new climatic circumstances. In this respect there is likely to be a major difference between rights-based legal systems (even when it comes to natural resources) and those systems that see natural resources, such as water, as a common or public good.

\footnotetext{
${ }^{19}$ UNFCCC, art. 3 (1).

${ }^{20}$ UNFCCC, art. 3 (2).

${ }^{21}$ UNFCCC, art. 3 (3).

22 UNFCCC, art. 3 (4).

23 UNFCCC, art. 3 (5).

24 The analysis of the principles based on the UNFCCC is based on the Ph.D. research of Teresa Thorp at Utrecht University on principles in international climate law.
} 
The principles of equity and solidarity therefore require that a fair distribution of benefits and costs takes place in national or regional climate-adaptation policies. ${ }^{25}$ In our opinion, the equity principle should preferably be based on the idea that a certain level of protection is provided for all (safety, availability of water, a basic quality of the living environment) because it is necessary to protect human values. ${ }^{26}$ The main argument for this comes from the human rights approach as laid down in, for example, human rights treaties. After protecting these basic needs of the population, there is still, in most instances, a policy discretion for the government when it comes to adaptation to climate change. This is where the solidarity principle joins in. If the choice is made to offer certain groups a higher level of protection or to protect their interests in particular, then the reasons for doing so must be accurately stated, so that in democratic decision-making it is clear why certain interests must be given more protection than others.

A well-known example is the protection of national agriculture, originally meant to ensure that there will be enough food for a state's own population - a choice that many people would agree with. But nowadays the protection of agriculture, which has severe impacts on the environment, is much more diffuse in the goals and interests that are being served. Another example is energy supply, which is crucial to a modern society. Protecting the energy supply often leaves unanswered the question about whether the vested interests of oil companies should be allowed to frustrate new, innovative, and environmentally friendly solutions.

In this sense, equity and solidarity, including substantive, procedural, and distributive fairness, do not, by definition, mean "equality", but should in our view ensure a fair distribution of wealth and risks. Francot-Timmermans and De Vries state that justice and solidarity should be the leading principles in situations when shifts of wealth or risks are at stake, and we believe that this should also be the case when it comes to adaptation to climate change. The aforementioned authors discuss the shift from the first to the second modernity, meaning a shift from a fair distribution of wealth towards a fair distribution of risks and responsibility for risks. The distribution of wealth is mainly based on cost-benefit calculations and is the major obstacle to the constitution of (global) solidarity. ${ }^{27}$ We see that this is also the case in the climate change debate, not only when it concerns mitigation but also in the case of adaptation. Certain circumstances may require more intense government involvement than others. This is the case, for example, when safety against flooding, food safety, and the protection of the supply of drinking water are concerned.

The following questions regarding the fair distribution of benefits and costs are always relevant and should be discussed in an open and transparent way:

\footnotetext{
${ }^{25}$ Dinah Shelton, Equity, in The Oxford Handbook of International Environmental Law, 639 (Daniel Bodansky, Jutta Brunné, and Ellen Hey, eds.); Rosalind Cook, supra note 13.

${ }^{26}$ Rosalind Cook and Eljalill Tauschinski, supra note 13.

${ }^{27}$ Lyana Francot-Timmermans and Ubaldus de Vries, Normativity in the Second Modernity, 39 Rechtstheorie 477 (2008). Their article is based on the work of, amongst others, U. Beck, Risk Society, Towards a new Modernity (1992). See also Lyana Francot and Ubaldus de Vries, As good as it gets: On Risk, Legality and the Precautionary Principle, in The eclipse of the legality principle in the European Union (Sacha Prechal (ed.) (2011); Jonas Ebbesson, supra note 11.
} 
- Whose interests are protected by a proposed adaptation measure?

- To what extent does a government wish to guarantee a certain level of protection for all without restrictions (drinking water, safety)?

- To what extent does a government wish to guarantee the above with certain restrictions, for instance by regulating or restricting functions, curtailing use, and imposing financial burdens? How are these restrictions shaped in terms of legislation or policy?

- To what extent do citizens and businesses have a responsibility to make adjustments to the impacts of climate change?

- Who pays for adaptation measures, and are payments to be based on solidarity or profit? May the measures be imposed on those who are not responsible for the causes of climate damage or the (over)use of natural resources?

- Does taking a proposed adaptation measure conflict with the protection of human rights, or the protection of habitats and species, ecosystems, or river basins? Does the measure lead to unequal competitiveness?

- Does the adaptation measure lead to a conflict with general international legal or national principles, such as the principles of subsidiarity, proportionality, polluter-pays, and precaution?

Many authors suggest that one of the most important principles that should be taken as the basis for a climate-adaptation policy is the precautionary principle. ${ }^{28}$ The European Environment Agency defines this principle as follows: "The precautionary principle provides justification for public policy actions in situations of scientific complexity, uncertainty and ignorance, where there may be a need to act in order to avoid, or reduce, potentially serious or irreversible threats to health of the environment, using an appropriate level of scientific evidence, and taking into account the likely pros and cons of action and inaction". ${ }^{29}$ The precautionary principle thus requires risk assessments. The UNFCCC sees mitigation and adaptation measures as elements, or more precisely as risk-regulation tools, of a precautionary approach. Contrary to the meaning of the precautionary principle in, for example, the European Union's natureconservation legislation, the UNFCCC explicitly and generally (without exceptions) refers to the socio-economic context and the cost-effectiveness of measures to deal with climate change. ${ }^{30}$

\footnotetext{
${ }^{28}$ See Article 3 EU Treaty; Communication from the Commission of 2 February 2000 on the precautionary principle; Nicolas Sadeleer (ed.), Implementing the precautionary principle: approaches from the Nordic countries, EU and USA (2007); Arie Trouwborst, Precautionary Rights and Duties of States (2006); Wybe T. Douma, The Precautionary principle: Its application in International, European and Dutch Law (2004); Arie Trouwborst, Evolution and Status of the Precautionary Principle (2002).

${ }^{29}$ European Environmental Agency, Late lessons from early warnings: the precautionary principle 1896-2000, EEA 2002.

${ }^{30}$ Arie Trouwborst, Conserving European Biodiversity in a Changing Climate: The Bern Convention, The European Union Birds and Habitats Directives and the Adaptation of nature to Climate Change, 20(1) RECIEL 62 (2011); Jonathan Verschuuren, Effectiveness of nature protection legislation in the European Union and the United States: The Habitats Directive and the Endangered Species Act, in Cultural Landscapes and land Use: The Nature Conservation-Society Interface (M. Dieterich et al.), 39 (2004).
} 
In the past few years an attempt has been made to provide a more adaptive definition of the precautionary principle. In so doing, one departs from the strict approach in, for example, natureconservation law-where no activity is permitted unless there is a guarantee that no damage will occur-and tends towards an approach that leaves room for new solutions and in which certain risks are tolerated. In order to achieve an adequate-but not absolute-level of protection and to place the risk of any damage with the initiator of the action, an accountability regime is used which, for example, reverses the burden of proof. ${ }^{31}$ Policies on substances and products, as well as liability regimes, aim to provide relevant solutions. In this way, innovative developments and activities that are essential within the framework of climate adaptation can still go ahead-and developments are not blocked because of the uncertainties that play a role in decision-making.

The next principle is that of sustainable development, or sustainability, based on Article 3(4) of the UNFCCC. ${ }^{32}$ It expresses the non-shift principle, which, among other things, aims to prevent responsibility for environmental problems from being shifted from one area to another, or shifted to future generations. Where adaptation measures are necessary in the field of water management, the river-basin approach based on the Helsinki Treaty is relevant, and this also requires the non-shift principle. Thus, for example, safety measures to adapt to climate change may not lead to a higher level of unsafe situations later or elsewhere.

The principle of good neighbourliness follows directly from the UNFCCC, but can be found in other environmental and water treaties. It comprises an obligation to cooperate and not to cause harm.

\section{Other Relevant International Law Principles}

The principles following directly from the UNFCCC are not the only principles that can be important for initiating and shaping an adaptation policy. ${ }^{33}$ The following principles are important as well: the principle of proportionality, ${ }^{34}$ the principle of subsidiarity, ${ }^{35}$ and the cost-recovery principle $^{36}$ (including the polluter-pays principle ${ }^{37}$ ).

The principle of proportionality implies that the government must not overreact in its policy ambitions but must limit itself to measures that serve the collective interest and should leave

\footnotetext{
${ }^{31}$ Alan Randall, Risk and Precaution (2011); and see for the discussion in the Dutch legal literature: Ben J. Schueler, Het vernieuwde voorzorgsbeginsel als toetsingsmaatstaf voor de bestuursrechter, in Bij twijfel (niet) doen? Over de invulling van het voorzorgsbeginsel en het omgaan met onzekerheden (Natasja Teesing (ed.) 15 (2009); Roel Pieterman, T. Arnoldussen and W. J. Kortleven, Voorzorg en Integraliteit, in Bij twijfel (niet) doen? Over de invulling van het voorzorgsbeginsel en het omgaan met onzekerheden (Natasja Teesing (ed.) 31 (2009).

${ }^{32}$ See for the European counterpart Article 3 of the EU Treaty.

${ }^{33}$ See for an emergency-based approach: Robin K. Craig, Stationary is Dead, Long Live Transformation: Five Principles for Climate Change Adaptation Law, from the selected works of Robin K. Craig, 2009, at $<\mathrm{http} /$ works.bepress.com/robin_craig/4>.

${ }^{34}$ See e.g. Art. 5 of the EU Treaty.

${ }^{35}$ See e.g. Art. 5 (3) of the EU Treaty.

${ }^{36}$ See e.g. Art. 9 of the Water Framework Directive (WFD).

${ }^{37}$ See e.g. Art. 191(2) of the Treaty on the Functioning of the European Union (TFEU).
} 
sufficient latitude for the market. ${ }^{38}$ The proportionality principle is important when an adaptation policy is based on a programmatic approach. Measures should be related to causes and should also be proportionate regarding the costs as well as the benefits. This helps clarify how the several climate-adaptation principles are interwoven, since proportionality is also linked to distributive fairness and substantive and procedural fairness. It therefore requires not only a programme of measures that could solve the problem, but also a programme that is transparent and open to public participation and judicial review. In a legal system that aims to protect the interests of its citizens, it should be possible that the courts are able to judge the fairness and proportionality of adaptation measures.

An example from the Netherlands in this respect is the advice of the Dutch Delta Commission to improve protection against flooding. The Delta Commission was asked by the Dutch government to provide advice on the necessary water-management adaptation strategy for the coming decades. The Commission suggested that future dike improvements should not only be based on scientific research on expected sea-level rise, but that the necessary dike-reinforcement standards should be multiplied by a factor of ten so as to ensure that the country will be well protected for the coming decades. It might be said that this is in breach of the proportionality principle, for it inflicts enormous costs and other impacts on the living standards of those living near dikes, who in the Netherlands must pay for dike enforcements. On the other hand, if one's main concern is preventive action, it could be seen as good advice.

The principle of subsidiarity is allied to the concept of decentralization and means that something should be regulated at a higher government level only if it is essential to achieve the objectives of adaptation to climate change. The principle of subsidiarity advocates national and regional adaptation strategies where possible. Patrick Huntjes refers to this as the need to improve adaptive governance through systems that are more polycentric. ${ }^{39}$

European adaptation policy is based on the subsidiarity principle, as reflected in the Water Framework Directive and the Directive on Flood Risk Management, among other policy measures and legal tools. They all leave some, or a great deal, of policy discretion to EU member states. The Directive on Flood Risk Management ${ }^{40}$ sets no safety standards at the European level, nor does it prescribe any specific safety measures. All that states have to do is to provide an overview of historical flooding and future risks and prepare risk-management plans. The content and the institutional organization of flood-risk management are left to the individual states. Basing adaptation strategies on the subsidiarity principle means that (major) differences in levels of protection may exist between states, regions, provinces, or municipalities. If a national government is of the view that all its citizens should be equally protected, it may be necessary to set binding and enforceable safety standards at the national level. For example, in the Netherlands flood

\footnotetext{
${ }^{38}$ Takis Tridimas, The General principles of EU Law (2006).

${ }^{39}$ Patrick Huntjes, Water Management and Water Governance in a Changing Climate, Experiences and insights on climate change adaptation in Europe, Africa, Asia and Australia (2010), 43-44.

${ }^{40}$ Directive 2006/60/EC.
} 
safety is traditionally decentralized, although safety standards are set at the national level. The government plays a role in flood protection only in those areas that are protected by dikes. Those who choose to live on river flood plains or on the coast must take their own safety measures. In these areas citizens and the market can operate freely. However, the government must be fully transparent about where governmental responsibilities end and private responsibilities begin.

Another relevant principle is the cost-recovery principle: the costs incurred must be able to be recovered from those that benefit. This principle is a combination of the polluter-pays and the user-pays principles. A heavily debated adaptation measure in the Netherlands is the planned increase in the water level of Lake IJssel to ensure a fresh water supply for farmers in the South-West Delta region. Flood-protection measures would have to be taken to guarantee the safety of those living near the lake. The impact on the landscape, living conditions, recreation, and other economic activities will be huge. Under the current system, the measures have to be paid for by those living near the lake and not by the farmers who will benefit from the adopted measures.

The cost-recovery principle could lead to a dilemma involving the direct-benefit principle and the principle of solidarity. The principle of solidarity is, as stated above, of essential importance in climate policy, yet it is often understood as referring to solidarity with countries experiencing the impacts of climate change though they have contributed little to the causes of the problem. The solidarity principle should also play a role in decision-making at the regional and national levels, for example when the subject is the protection of human rights, such as the right to sufficient drinking water.

\section{Which Interests Must be Protected by Means of Adaptation to Climate Change - AND IN Which ORder?}

Adaptation policy will generally focus on reducing the vulnerability of countries and regions to flooding, heat stress, aridity, etc., and increasing the level of resilience. In this respect many interests are at stake, such as the interests of economic sectors, the interests of the proper functioning of basic networks and facilities, and those of public health. When formulating adaptation options there is often a tendency not to depart too noticeably from assumptions about the degree to which those interests must be protected. Path dependency plays an important role in this respect. Path dependency means that (normative) choices made in the past also determine the choices to be made now. ${ }^{41}$ In other words, choices made in the past tend to rule out options now. Two examples taken from experience with Dutch adaptation policy illustrate this.

The Netherlands is faced with an increasing level of salinity in the western part of the country caused by a rising sea level and subsidence. The question is how to deal with this phenomenon in order to ensure that existing agricultural activities are not endangered. After all, those agricultural

\footnotetext{
${ }^{41}$ Paul Pierson, Increasing returns, path dependence, and the study of politics, 94(2) American Political Science Review 251 (2000).
} 
activities go back many years, over which time they flourished economically. The question could also be asked, though, whether there are any opportunities for so-called "saline agriculture"- and the degree to which the agricultural sector is capable of making a radical change in that direction.

The ground-water level in the western part of the Netherlands must be substantially and continuously artificially lowered to make conventional agricultural activities possible. Adaptation in this respect could focus on increasing pumping capacity to ensure that surplus water can be pumped away in the future. This solution is in line with the methods that have been used for centuries. An alternative would be to stop, or to drastically limit, the lowering of the groundwater level and to shift highly productive agriculture away from the area. In this scenario, the area would have a different function; small-scale and marginal agricultural activities would co-exist with nature and landscape development, extensive development of recreational activities, and water storage to avoid flooding and to conserve water for times of drought. The key question here is the degree to which we wish to protect or perpetuate the existing order at any cost, or are prepared to open the matter up for debate and put forward proposals for a new order in which the opportunities that arise are fully exploited.

We believe that the following questions should be taken into consideration in a political and governance assessment of adaptation:

- What are the costs of the various adaptation options and what benefits (not only economic) do they offer?

- What are the national, regional, societal, and economic effects of the different adaptation options for the various economic functions?

- What are the consequences of various adaptation options for the functioning of different networks and infrastructure?

- What is the effect on the quality of the living environment (water quality, historical and cultural values, nature and landscape values, land use, multi-functionality, sustainability, etc.)?

- What are the consequences of adaptation options for the international reputation of different economic sectors?

- To what extent do adaptation options create new opportunities for different economic functions and what benefits can be expected thereof?

Priorities must be established when determining the content of an adaptation policy: which adaptation measures have priority over other measures? Considering that climate adaptation will go hand-in-hand with substantial investments, not all measures will be able to be implemented simultaneously. For instance, consideration must be given to whether the drinking-water supply, as an acknowledged human right, should be given priority, or whether priority should be given to protection against high water levels, or the concern for a safe infrastructure, reducing publichealth risks, ensuring a supply of food, etc. The following considerations can play a role when setting priorities in this area: 
- Which measures are urgent from the perspective of gravity and necessity (prioritizing according to urgency)?

- What is the most logical temporal order for the adaptation measures, from a technical, ecological, and rational point of view (prioritizing according to timing)?

- When is it economically most profitable to make investments in long-term adaptation measures (prioritizing according to cost-effectiveness)?

- Which measures must be taken and on which scale-international, national, regional, local (prioritizing according to scale)?

- Which measures could draw major societal and political support (prioritizing according to support)?

- Which measures could be supported with sufficient financial means (prioritizing according to the available budget)?

\section{Who is Responsible for Climate Adaptation?}

The question as to the extent to which the government is responsible for adaptation to climate change, and the responsibilities that should be borne by private parties and citizens, is a difficult one to answer. There is a choice here between two partly overlapping but analytically distinguishable approaches: a legal approach, on the one hand, and an administrative/economic one, on the other. Unambiguous answers can be given for the legal approach, at least where international and national obligations are concerned. For the second approach, the answers are more ambiguous.

\section{Legal Approach}

Law's place in climate adaptation is characterized by the legal method and by a number of "firm" boundaries, that is: human rights; international law (especially in the field of environmental and nature-conservation law); national constitutions; and legal principles such as the principle of legal certainty, the principle of equality, the protection of property and right to compensation, and judicial review. Both European law and national legislation indicate (not always directly) the fields in which the government has a duty of care for adaptation to climate change, ${ }^{42}$ such as care for human habitation and the protection of the living environment. In many countries the government also has a duty to provide for education, health, and employment. These duties are frequently laid down in the wording of treaties, constitutions, and ordinary legislation. The development of duties of care is usually carried out in ordinary legislation, and can be assessed by the courts in terms of the legitimacy of the decision-making process. ${ }^{43}$ When the courts assess

\footnotetext{
${ }^{42}$ See e.g., Art. 3(3) of the Treaty on European Union; Art. 191 of the Treaty on the Functioning of the European Union; Art. 37 of the Charter of Fundamental Rights of the European Union. In the Netherlands, this follows from social human rights as laid down in the Dutch Constitution.

${ }^{43}$ Helena van Rijswick, The Status of Consumers in European Water Regulation, 1 European Journal of Consumer Law/Revue Europénne de droit de la consummation, 115 (2011), and Herman Havekes and Helena van Rijswick, Waterrecht in Nederland (Water law in the Netherlands) at 15-16 and 285-296 (2010).
} 
whether there is a fair distribution of benefits and costs, the principle of equality will play an important role. ${ }^{44}$ Everyone is responsible for his or her own loss, but in special cases, such as when an individual is affected more than others by a governmental action, he or she may be entitled to compensation. To be eligible for compensation, the loss must generally relate to circumstances that go beyond the scope of normal societal risk. In the years ahead, the question about the extent to which losses arising from governmental measures taken within the framework of climate adaptation are eligible for compensation will need to be reconsidered. Furthermore, distributive fairness also requires transparency in the choices that have been made.

\section{A. Functions of the Law in Climate Policy}

Law has a safeguarding function, a function within the framework of dispute resolution, and a function as a policy instrument. The safeguarding function guarantees that citizens are able to feel secure in a state - that they have a trustworthy government. For instance, the protection of property should ensure that the government is unable to use the land owned by a private individual for the purpose of building dikes or water-storage areas without expropriation or compensation. The interests which the government pledges to protect also fall within the scope of the safeguarding function, for example by regulating that the provision of drinking water is guaranteed. Abusing vested competencies or intervening in the lives of citizens without authorization is prevented by means of the safeguarding function of the law.

Dispute resolution provides for the opportunity to bring any dispute before an independent court or tribunal. Certainly, if the matter concerns an infringement of proprietary rights involving an element of confiscation, this is an acknowledged requirement. This does not, however, deny that many disputes can be resolved in an alternative manner, and further research is required to improve the potential of alternative dispute settlement, not only for disputes between public and private parties but also between private parties themselves and among several public parties. Adaptation to climate change will require challenging arrangements and sometimes painful measures. This in turn will require adequate dispute-resolution mechanisms, which should be accessible to all whose interests are at stake. ${ }^{45}$

An increasingly popular function of the law is that it acts as an instrumental policy tool, which becomes stronger the more the government becomes involved with all kinds of policies. Law is then used as a policy instrument which, in turn, can lead to an excess of detailed regulations, and may consequently lead to an inability to respond adequately to changes and innovative solutions. Two sides of the law, the safeguarding function and the instrumental function, are further discussed below.

\footnotetext{
${ }^{44}$ It must be pointed out that this principle can be implemented in very different ways in different countries.

${ }^{45}$ See Farhana Sultana and Alex Loftus (eds.), The Right to Water: Politics, Governance and Social Struggles (2011).
} 


\section{B. Safeguarding Function of Law}

Safeguarding elements are not only the rule of law and legal certainty but also binding environmental-safety and quality standards that aim to protect and guarantee a certain level of protection for citizens. ${ }^{46}$ This safeguarding function is sometimes seen as obstructive and counterproductive for economic development and the solution of societal problems, which has led to it being characterized as juridification that has gone too far. Certain scholars argue that parts of the law should be replaced by less stringent forms of top-down regulation and control. ${ }^{47}$ Others are concerned about a diminishing level of protection in the shift from government to "governance". ${ }^{48}$ For example, in the Netherlands it is fervently advocated that legal protection should be replaced by consultation and public participation. Nevertheless, significant risks and disadvantages attach to such a choice. The rule of law should remain the backbone and fundamental value of modern society, ${ }^{49}$ also when we have to cope with challenges such as economic crises and climate change. Especially in times of transition, the government should be a trustful partner and should be transparent and reliable when it comes to the protection level that is offered, and therefore should also be subject to the rule of law, including judicial review. Today, a greater value is being attached to procedural guarantees, such as transparency, equal access to information, and public participation-not instead of, but in addition to legal certainty and the legitimacy of norms. ${ }^{50}$

The concept of a state subject to the rule of law also has disadvantages. It is strongly focused on institutional and juridical aspects and on how a state should be structured and which regulatory norms should be effective, yet giving little indication about what a government ought to do. This state is based on the idea that citizens are free, self-aware, enterprising individuals who want to see the least possible degree of state intervention in their affairs, and maximum protection of their freedoms. ${ }^{51}$ While it has been suggested that protection against the effects of climate change is best be provided by private parties, ${ }^{52}$ another possibility is that "the people" decide that the government takes responsibility for adaptation to climate change. ${ }^{53} \mathrm{~A}$ fundamental social

\footnotetext{
46 Van Rijswick, supra note 11.

${ }^{47}$ Charles Sabel and Jonathan Zeitlin, Experimentalist Governance in the European Union: Towards a New Architecture (2010); Maria Lee, EU Environmental Law, Challenges, Change and Decision-making (2005); Anne M. Kjaer, Governance (2004).

${ }^{48}$ Ludwig Krämer, Thirty years of EC Environmental Law: Perspectives and Prospectives, 2 Yearbook of European Environmental Law 155 (2002).

${ }^{49}$ See, for instance, Art. 15 of the Treaty on the Functioning of the European Union. A classic definition of a state subject to the rule of law is that there exists a constitution that contains binding regulations on the relationship between the government and citizens, and in which a separation of powers is assured, particularly legislation in unison with parliament, an independent judiciary that not only rules on disputes between citizens themselves but also on disputes between citizens and the government, and governmental action which is based on the law, and by which fundamental rights or the citizens' rights of freedom are defined and guaranteed.

${ }^{50}$ Maria Lee supra note 47 and A. M. Kjaer supra note 47.

${ }^{51}$ Robert Nozick, Anarchy, State, and Utopia (1974) 29-34. See also Will Kymlicka, Contemporary Political Philosophy: An Introduction (2002) 106, and Jurrien Hamer, supra note 16.

52 Jonathan H. Adler, Taking Property Rights Seriously: The Case of Climate Change (2009) 296.

${ }^{53}$ E. R. Alexander, The public interest in planning: From legitimation to substantive plan evaluation, 1(3) Planning Theory 226 (2002); Jutta Brunnée and Stephen T. Toope, supra note 11.
} 
right that compels the government to ensure a country's habitability and to protect and improve the living environment is essential within the framework of a climate-adaptation policy. In other words, social rights do exist, for instance concerning economic development, protection against flooding, and the protection of the quality of the living environment, including measures against heat stress in urban areas. It is much better to speak of a duty of care of the governmental for the protection of certain interests, given that these rights generally cannot be directly enforced by a court of law. ${ }^{54}$ In addition to the assigned duties of care, the (legal) nature of the interests that must be protected is also relevant, such as the question whether it concerns the protection of public goods (the atmosphere, water, the countryside), ${ }^{55}$ the accessibility and availability of public works (e.g. the infrastructure) and the order or priority of the interests to be protected (such as the drinking-water supply, electricity, infrastructure, nature and safety in the event of flooding, the protection of public health).

However, two important comments are in order. In the first place, the fact that the government takes responsibility for certain tasks does not clarify what that duty of care entails. This gives rise to at least five questions:

- Does the duty of care imply that the government protects certain interests by drawing up regulations, or should the government take and finance the measures itself?

- What level of protection must guide government actions? For instance, is everyone entitled to the same level of safety, fresh water, and land use at all times?

- What kinds of regulation does the government want to implement? Classic command-andcontrol instruments (by means of legislation and regulation), market-based instruments, or communicative instruments?

- Should all the measures be taken by the government, be it the central or regional government? Will those measures be paid for by the state budget (and general tax revenue), or regional budgets, or should the cost be redeemed from those who benefit from them?

- Which measures must actually be taken, and by whom and how must they be attuned to measures taken in other areas of policy that touch upon the climate issue?

Secondly, the fact that the government takes responsibility for a certain task does not mean that all interests must be fully protected by the government in all circumstances. This point also gives rise to fundamental questions:

- Should safety be totally guaranteed by the government and unconditionally in all regions and for all functions?

${ }^{54}$ Van Rijswick, supra note 11.

${ }^{55}$ It makes a huge difference when dealing with drought, whether a state has a legal system in which for example water is regarded a common or public good or whether the legal system is based on property rights. See among others Ingrid Kissling-Näf and Stefan Kuks (eds.), The evolution of National Water Regimes in Europe, Transitions in Water Rights and Water Policies towards Sustainability (2004), and for a more international overview Joseph W. Dellapenna and Joyeeta Gupta (eds.), The Evolution of the Law and Politics of Water (2009). 
- Should the government ensure that everyone has access to a free and unlimited supply of fresh water at all times and for all users or functions?

- Are nature-conservation and nature-development interests always protected, or only insofar as they arise by virtue of international obligations, or does the national government still have an additional role to play in this respect? Regarding the question as to where and when nature conservation and nature development takes place, must the possibility or the desirability of locating this in specific regions be the guiding principle?

An important precondition for climate-adaptation policy is that adequate attention is paid to democratic decision-making, the separation of powers, and a system of checks and balances, the legality of government action, and also the existence of fundamental rights, legal and policy principles of good governance, adaptation management, and an adequate system of legal protection.

Whether the resilience of the legal system could be improved without losing its classical benefits is worthy of further research. For instance, setting standards today more often takes place at different government levels (international, supranational, national, regional) and by both private and public parties. The same applies with regard to enforcement. Arbitration and alternative mechanisms for dispute resolution could be an alternative to lengthy judicial procedures, while the effectiveness of judicial dispute resolution itself could also be improved.

\section{Law as a Policy Instrument}

The second important role of the law is as a policy instrument. This is the role that usually receives the most attention because many statutory regulations are realized within this framework on the international, supranational, national, and regional levels. One important research theme relates to the effectiveness of the system of regulations and norms which should preferably be studied from the social-scientific perspective. The effectiveness of the various judicial-control instruments can vary to a large extent, and the correct choice depends on the problem that needs to be resolved. Whether the current trend to replace classic control instruments with softer, informal, or economic-control instruments will really lead to faster and better results in the field of adaptation has not been empirically studied as yet. This is also why the guarantee function described above should be regarded as preconditional, so that a fair distribution of wealth and risks is guaranteed and sufficient protection against government action is assured. When making a choice for the appropriate policy instruments, attention must be given to the following aspects: ${ }^{56}$

- The urgency of the problem, which can call for speedy decision-making procedures. ${ }^{57}$

\footnotetext{
${ }^{56}$ Most of these subjects are elaborated and accompanied by further literature in Catrien Termeer et al., supra note 4.

${ }^{57}$ An example can be found in the Dutch Deltawet Grote rivieren (Delta (Major Rivers) Act), an emergency Act which provided for an expeditious procedure to improve and restore dikes after the severe flood risks in 1993 and 1995. The procedural system used in this Act was subsequently integrated into the regular Water Act of 2009.
} 
- Dealing with uncertainties, which calls for a fair distribution of risk ${ }^{58}$ e.g. by means of liability regimes that are in line with the precautionary principle $;{ }^{59}$ and monitoring obligations combined with flexible standards to ensure that regulations and standards can be adjusted to changed climatic circumstances.

- A just distribution of benefits and costs among various groups of stakeholders, in which it must be clearly set out which citizens' interests the government must at a minimum guarantee to protect. This may well be done through a transparent and enforceable programmatic approach.

- The significance of alternative policy instruments in which classic command-and-control is replaced by more market-oriented instruments, such as tradable rights.

- The introduction of forms of discussion and collaboration within networks. This is in addition to assigning care and management tasks and the associated competencies to a specific government body or within a certain area of policy ${ }^{60}$ When implementing forms of discussion and collaboration within networks it is precarious to use them in place of the care and management tasks of specific government bodies because it can diminish the responsibility and legitimacy of government action. It must be made clear exactly which government should protect which interests, and it is essential that citizens can also rely on the courts in this respect.

- The distribution of responsibilities between the state and citizens, and the associated demand for more or less generally formulated or detailed regulations.

\section{The Administrative, Economic Approach}

The law provides a number of pointers as to which responsibilities should in any case be borne by the government if the matter of concern is climate adaptation. The safeguarding function of the law leads to the conclusion that in a climate-adaptation policy the government must in any case ensure a fair distribution of benefits, costs, and risks, and that citizens are protected against government action. The control function implies that the government may intentionally and specifically intervene in societal processes with a view to the habitability of a country, including adaptation to climate change. And yet this still does not answer the question of where and when the government must and must not act, and when responsibilities can be shifted elsewhere.

That the government takes the lead in all areas of social concern is not a given. History shows that certain tasks shuttle back and forth between the government and the market. For decades in the Netherlands the government was the decisive player in some policy areas, for example, in the fields of supplying energy, waste removal, public transport, and the distribution of mail, but these tasks have now been handed over to the market, in the Netherlands and elsewhere.

${ }^{58}$ Alan Randall supra note 31; Lyana Francot-Timmermans and Ubaldus de Vries supra note 27.

${ }^{59}$ Ben J. Schueler, Governmental liability: an incentive for appropriate adaptation? in Climate Change Liability (Michael Faure and Marjan Peeters, eds.) (2010).

${ }^{60}$ Marco A. Janssen, An update on the scholarly networks on resilience, vulnerability, and adaptation within the human dimensions of global environmental change, 12(2) Ecology and Society 9 (2007); and Marco A. Janssen et al., Towards a network perspective on the resilience of social-ecological systems, 11 Ecology and Society 1 (2006). 
The opposite is also sometimes the case; tasks which had previously been in the hands of the private sector have been taken over by the government. For example, nature conservation in the Netherlands during the first half of the twentieth century was mainly in the hands of NGOs. Only in the second half of the century did this become a prominent area of government care.

Three alternatives to governmental management are distinguished in the literature: selfregulation, management through market mechanisms, and interaction between the government and private parties. ${ }^{61}$ Self-regulation implies that citizens and NGOs themselves disseminate social values and solve social problems. This is the case, for instance, when private organizations take it upon themselves to see that existing housing and existing residential areas are climate-proofed, e.g. via the laying of green roofs, open-space planning, the temporary storage of rain water, etc. This is also the case when NGOs undertake communication activities that contribute to a greater awareness of the consequences of climate change, and businesses and citizens are urged to take adaptation measures themselves. Management via market mechanisms can be effective if there is an adequate number of suppliers of goods and services. The consumer or user can then make his or her choice on the basis of cost and quality levels. As far as climate adaptation is concerned, consideration could be given to a market for flood insurance, a market for heat-resistant dwellings, or a market for laying green roofs (as a remedy for heat stress and urban flooding). Interaction between the government and private parties can also be a good alternative to governmental care. For instance, the government can facilitate initiatives taken by private parties to take action in terms of climate adaptation. The government can also commission studies on the feasibility of specific adaptation options which can subsequently be implemented by private parties. The government can also either stimulate or curb specific behaviour through subsidies and levies. The laying of green roofs could be stimulated by means of subsidies, and surface paving or asphalting in urban areas (possibly resulting in the quicker drainage of rain water) could be discouraged by means of levies.

It goes without saying that reasons can always be put forward to have the government take the lead in adapting to climate change. ${ }^{62}$ The first reason could be that citizens, NGOs, and private companies are unable to take care of the production of collective goods. Safety against flooding (and the associated infrastructural facilities in the form of dikes and other constructions) can, for instance, be seen as a collective good. All citizens benefit from them but no one will be inclined to invest in them. However, if an individual does make such an investment, then other people will display free-rider behaviour because no one can be excluded from safety measures (e.g. dikes). It is obvious that in such a case the government takes responsibility for that care. New health threats that can arise from climate change can also be a reason for the government to take action; in such cases, public health is regarded as a collective good.

\footnotetext{
${ }^{61}$ Peter P. J. Driessen and Pieter Glasbergen, Greening society; the paradigm shift in Dutch environmental politics (2002).

${ }^{62}$ Mark A. P. Bovens, P. 't Hart and M. J. W. van Twist, Openbaar bestuur; beleid, organisatie en politiek (2007), 88-97.
} 
The second reason for governmental management has to do with regulating external effects. These are the effects of our economic and social activities that cannot be discounted in the price of goods and services. Building in areas that are vulnerable to flash flooding - for instance in the vicinity of rivers - can involve extra risks and therefore extra costs, and for this reason can or should be regulated by the government. The extraction of ground water by the agricultural sector can-especially during dry periods, which will increase due to climate change-damage nearby nature-conservation areas and thus can be regulated by the government. Another example is that measures focusing on the faster drainage and lowering of high-water levels in the major rivers in one region can lead to a higher risk of flooding in another region downstream. This relates to the non-shift principle, referred to earlier. It calls for government regulation, at least in the form of coordinated action.

The third reason for government action in connection with climate adaptation can be in the field of controlling goods. The market can offer products that are unwelcome within the framework of curbing the climate issue. As a result of climate change, cities can become hotter during the summer months (partly as a result of the urban island effect). There is a greatly increased possibility that citizens will then purchase air conditioners on a large scale, leading to the higher consumption of electricity and most probably to higher $\mathrm{CO}_{2}$ emissions. The government could intervene and impose a levy on (or even prohibit) the purchase of such equipment.

The fourth reason for government action in the field of climate adaptation has to do with compensating the distributional effects. ${ }^{63}$ Social inequality can arise-often unintentionally-because of government policy and market mechanisms. In this connection the instrument of compensation is frequently used. Compensation is basically a financial instrument which intends to resolve imbalances between the revenues and charges of a project felt by different stakeholders. Allocating an area for the temporary storage of water, from which many can benefit, can have consequences for the nature and intensity of the usage of that area and can be detrimental to the owner/user. Government action must therefore be geared towards restoring the balance between collective benefits and individual costs, for example, by paying damages.

Although legitimate reasons can be given for government control in the area of climate adaptation, that control is not always executed without problems. The government can also fail, as can the market. Known issues connected with government control are a delay in responding to problems, the inadequate implementation of the government's own policies, and the poor coordination of policy among the administrative layers.

If the government takes the initiative on implementing adaptation measures, it need not be the case that the central government is the leading actor. The central government can also leave the initiative up to regional and local authorities, or rather establish conditions under which regional and local authorities are able to execute this task properly, for instance by setting up specific

\footnotetext{
${ }^{63}$ Peter P. J. Driessen and Tejo Spit, De bekostiging van klimaatadaptatie: arrangementen voor een legitieme balans van baten en lasten, 37(1) Beleid and Maatschappij 73 (2010).
} 
funds that can be used to take adaptation measures. Over the past few years, the interaction between governments in many Western countries has increasingly been structured by virtue of agreements and contracts. This trend is sometimes referred to as new public management. ${ }^{64}$ The guiding principles in this respect are results orientation, businesslike management, competition in public administration, and benchmarking. Especially the granting of funds by central government to local authorities can be directly coupled to performance; the budgetary amount is then dependent on the amount of success achieved. Local authorities then compete against each other for funding. In the case of climate adaptation, the central government could provide regional governments with funding on the basis of agreements regarding performance. For that matter, the spatial scale on which adaptation measures are taken is determined not only according to considerations of suitability but also according to considerations of effectiveness. It is evident that in the Netherlands measures taken against flooding should not be left to local authorities, but that may be different in other countries. The same applies with regard to the supply of fresh water and safeguarding national energy or the transport infrastructure. But limiting urban flooding, combating heat stress, and fighting drought can easily be left to regional governments and local authorities.

Furthermore, it must be pointed out that the above discussion relates mainly to the question of who has the prime responsibility for adaptation to climate change, or at least who should take the initiative in this respect. The question of who should pay for this, or who should take the necessary measures, can be of an entirely different order. The central government can take the initiative for far-reaching safety measures but recoup the cost thereof from those who benefit most (by way of a levy or a special tax). The central government could assign the execution of those measures to regional authorities that also have statutory powers in this respect.

\section{Concluding Remarks}

We have given an analysis of the normative side of climate-adaptation policy from different angles. It is essential to devote attention to the normative aspects because they-as well as the physical characteristics of the phenomenon of climate change and its impacts-help to determine the choice between the various policy instruments to be deployed and the measures that need to be taken. We argue that the aforementioned normative aspects need to be explicitly discussed in climate-adaptation policy processes: the questions have to be raised in every debate about climate adaptation and the related aspects have to be considered. Legal and policy principles can be used in motivating societal interventions aimed at the adaptation to climate change. Moreover, based on these principles, a choice can be made on the societal changes that are necessary, possible, feasible, and acceptable. Finally, responsibilities for public or private interventions have to be determined.

\footnotetext{
${ }^{64}$ David Osborne and Ted Gabler, Reinventing Government: How the Entrepreneurial Spirit is Transforming the Public Sector (1992).
} 
The choice for public or private management depends primarily on the demands set by international and national law. Additionally, it is a choice that is mainly determined by current "tastes": decentralisation, deregulation, decreasing government involvement, the demand for strict management, more value attached to generating consensus, economic instruments, etc. Various considerations were discussed in the foregoing that can play a role in the choice between public or private management and the shaping of an adaptation policy. The global character of the phenomenon, the immense repercussions that climate change can have on the actual functioning of our society, and the opportunities that arise for social and economic development, are reasons enough not to place responsibility for this issue with societal actors alone. The issue calls for collective action. At the same time the issue is too complex, too controversial, and too value-laden for a quick switch to a centralist management dominated by the government, or to resolute government action, without paying attention to the normative points that we have discussed here. Tackling such issues necessitates the participation of, and discussion with, societal actors in an open and transparent way. Discussions must also include the normative choices that will be made, for example whether adaptation will mean that existing situations should be maintained, or major reforms will be undertaken to create new opportunities. Not only should there be room for scientific insights in that discussion but also for societal and legal principles, values, and interests. Only by means of this discussion is it possible to derive a legitimate role for government and simultaneously a clearer role for other parties in society. 